\title{
AGRICULTURAL COOPERATION: EXPERIENCE OF FOREIGN COUNTRIES FOR UKRAINE
}

\author{
Olena Sakovska ${ }^{1}$
}

\begin{abstract}
The purpose of this article is to analyze the experience of agricultural cooperation in foreign countries, such as Sweden, Norway, Finland, Japan and apply it in Ukraine. The defining feature is that the existing agricultural cooperation in Ukraine is not backed up by proper legislation to integrate with the European countries. Analyzing the state of agricultural cooperation in Ukraine in comparison with foreign countries, the country remains a number of unresolved issues regarding its normal functioning, namely: the activation of international economic cooperation of Ukraine involving the development of a strategy for the effective functioning of agricultural cooperation, which is the basis for ensuring the various areas of rural development employment of rural population. In addition, agricultural cooperation stimulates the development of agrarian market infrastructure, plays an exceptional role in strengthening the economic potential, competitiveness and social status of agricultural producers, improving economic conditions and creating incentives for the growth of commodity products. However, so far its development is at a low level, the main reasons being the underestimation in the process of economic reforms of cooperative forms of economic activity, general unfavorable conditions for agricultural production, psychological unwillingness of peasants to cooperate and insufficient knowledge of the rural population about the benefits of cooperation, weak state support for small businesses in agribusiness and agricultural cooperatives. Methods. The countries of the West in every way stimulate the development of cooperation: by appropriate laws, privileges, subsidies. Ukraine needs to take the example from these countries in order to develop the cooperative movement, which will stimulate rural development. Results. Ukraine is trying to build on the experience of different countries in the field of agricultural cooperation, backing up on the best of the countries studied. Practical implications. Studies have shown that world experience convinces that cooperation has contributed to the development of many countries in the world. In Europe, for example, cooperatives are an important part of economic life and industry. Value/originality. Analyzing the activities of agricultural cooperatives operating in the world, we point out that the main advantage of combining agricultural producers in cooperatives is a grower group (union or cooperative) is considered as the only powerful organization that is able to buy large volumes of products and services and realize large volumes of production.
\end{abstract}

Key words: Sweden, Norway, Finland, Japan, agricultural cooperation, foreign experience, legislation, Ukraine.

JEL Classification: D73, H70, H72, H77, R50

\section{Introduction}

Throughout the developed world, the efficiency of small and medium-sized agricultural producers is achieved by combining them for the purpose of joint production, access to financial and material resources and the promotion of their products. In turn, agricultural cooperatives are one of the most common and effective forms of such an integration, the share of which in the EU agricultural market is $40-50 \%$ and up to $70 \%$ in individual countries and sectors. The annual turnover of the 10 largest farmer cooperatives in the EU is over 93 billion USD, almost equal to the annual GDP of Ukraine.

The situation with the development of agricultural cooperation in Ukraine is quite different. The share of production agricultural cooperatives in the total volume of agricultural production in Ukraine is less than $1 \%$, and the number of individuals-members of agricultural service cooperatives is less than 30,000 people, that is, less than $0.2 \%$ of the rural population of Ukraine.

This is despite the fact, that a lot of resources have been invested in the development of agricultural cooperation in recent years, both by the state and by international technical assistance projects. The experts analyzed the reasons, hampering the development of agricultural cooperatives, and finally concluded, that the main of them is the imperfection of the current legislation and without its significant updating, some significant progress in the development of rural cooperation will not be possible.

\footnotetext{
Corresponding author:

${ }^{1}$ Uman National University of Horticulture, Ukraine.

E-mail: sakovska_lena@ukr.net

ORCID: https://orcid.org/0000-0003-2676-6170
} 


\section{Economic crisis effects on consumer behaviour}

Cooperative organizations are an integral part of the economic systems of the Member States of the European Union. Their role in the agrarian sector of these states is especially prominent. The activity of the EU cooperatives, based on the principles of democracy, transparency and solidarity, opens up access for farmers to financial and logistical resources, internal and external markets, and promotes the social and economic development of rural areas.

In the context of the European integration tendencies, which currently permeated the agrarian sector of the Ukrainian economy, the study of the experience of cooperation between farmers of the European countries can be useful both from the point of view of its adaptation to domestic realities and of the most significant mistakes and miscalculations in the development of the cooperative movement of these countries.

The key problem of the post-war Europe was starvation. For a long time, the main efforts of European states have been directed at its solution. The agrarian sector has begun to play a leading role in the context of food security of these countries. The Treaty of Rome establishing the European Economic Community, signed on March 25, 1957, contained the most important framework positions of the Common Agricultural Policy (CAP), aimed at solving hunger problems on the European continent.

\section{Differences in consumer spending behaviour among age groups}

The activities of cooperatives in the EU countries are based on the principles of economic democracy, transparency and solidarity with each other and with local rural communities. They play a vital role in the promoting the products of their members directly to consumers and improving their position in the markets, promote the production of environmentally friendly products; actively participate in the economic and social development of rural areas. Today, there are about 14 million farms and other agricultural production units directly involved in agriculture in the EU. The average farm size in the EU is less than 13 hectares. The largest farm sizes are in Denmark (about 59.7 hectares), in the United Kingdom (about 53.8 hectares), in France (over 52.1 hectares). On average, over $40 \%$ of farms are covered by cooperatives in EU countries.

The largest number of agricultural cooperative organizations operates in Italy (5834 units), in Spain (3844 units), in France and in Germany (2400 units each). At the same time, the largest number of members (1 440600 people) are attracted to the German (1 179323 people) and Spanish cooperatives. The highest annual sales turnover in 2017 were received by the French ( 84350 million EUR) and by German
(67 502 million EUR) cooperators. Agricultural cooperatives in almost all the European countries are widely supported by the state.

Most EU member states have created "specific legislation" for cooperatives, which gives them some freedom. In particular, the legislation, generally, does not provide for a standard cooperative management procedure, although, in most cases, cooperators adhere to the principle of "one member - one vote". A number of European countries do not set a minimum number of members in cooperatives (Denmark, Lithuania, Croatia and the Netherlands), however, some countries regulate such restrictions (Belgium, Italy, France). In most EU countries, cooperatives are subject to a common system of taxation without any exceptions or special rules (Austria, Belgium, Croatia, the Czech Republic, Denmark, Finland, France, Germany, Latvia and Romania). However, in France, cooperatives are subject to special tax arrangements, paying only corporate tax, regional fees and real estate tax. The Greek cooperatives are also exempt from multiple taxes. In the Netherlands, the law contributes to the reduction of taxable profits, resulting from economic transactions between members of a cooperative. Portugal has specific tax benefits for cooperatives.

\section{Survey methodology}

Ukraine's integration into the world economy is accompanied by the dependence of the national economy on the economies of the world. The Ukrainian cooperatives need the experience of developed and transition economies sphere of consumer cooperation. In the process of Ukraine's integration into the world cooperative movement, there is an opportunity to gain experience of cooperative activities abroad.

The cooperative movement of the countries of the European region during the 1920s was marked by organizational heterogeneity. For example, if in Hungary it was not only integrated into a national cooperative center, the Hungarian Cooperative Union, but also structured in consolidated organizations of consumer, credit and other forms of cooperation, then in Czechoslovakia and Poland the processes of integration of the cooperative movement continued during this period. This was determined by the peculiarities of the formation of their territories and the national composition of the population. In particular, Poland indicated the long entry of its territories to the three neighboring empires (the Russian, AustroHungarian and German), which underwent the processes of the genesis of the cooperative movement in the late 19th century. As a result, in Poland there were separate interdependent centers of all types of cooperation, and in Czechoslovakia there were separate national associations of agricultural and consumer cooperatives. The processes of consolidation 
of the cooperative movement ran into political and ideological contradictions between the political forces that controlled the centers. For this reason, the fragmentation of the Polish agricultural cooperative was overcome more slowly than the Czechoslovakian one. This was due not only to the lack of unity of local agrarianism, but also to the struggle for influence in a possible single center, which is the Central Union of Agricultural Cooperatives (Plakhtii, 2019).

The exacerbation of the conflict between the Communists and the moderate representation of the European cooperative society was also reflected in the work of the ICA. This is clearly reflected in the experience of Czechoslovakia. It is there the Communists had the strongest positions in the early 20s of the 20th century among the cooperative movements of all European countries. The Communist Party of Czechoslovakia created one of the first cooperative sections in Europe. In the Slavic part of the consumer movement, communists gained up to half their seats in cooperative congresses in the early 1920s, an unprecedented result among all capitalist cooperative centers. The official organ of the Cooperative Section of the Comintern Journal of International Cooperation in early 1925 acknowledged that: "Czechoslovakia is the only country in which our influence has spread to the broad masses of cooperative workers."

The economic systems of the countries of Central and Eastern Europe are most similar to the Ukrainian ones, so the positive tendencies in the cooperative movement of these countries can be applied to Ukraine. Development of the cooperative sector in transition economies, namely in the countries of Central and Eastern Europe

The cooperative activity of the EU countries is characterized by:

- high competitiveness of cooperative enterprises, due to the effect of scale and concentration of economic activity;

- high volume of operations (annual turnover ranges from 3.6 billion EUR in Portugal to 23.7 billion EUR in Denmark);

- state incentives for different types of cooperation;

- diversification and industrialization of traditional cooperatives;

- high level of integration of cooperatives from different branches of activity;

- an increase in tertiary sector cooperatives (banking, insurance, consumer cooperatives, retailers and credit unions) and service cooperatives, especially in the tourism sector;

- expansion of cooperatives by combining functions of production, logistics, marketing and service;

- implementation of innovations in cooperative activities;

- deepening the international integration of cooperatives.
In order to support and develop joint (pan-European) cooperative enterprises (organizations), a European Cooperative Union (ECO) was established in the EU. It includes 6 European cooperative associations and 171 national cooperative organizations from different countries of the European Union. The cooperative associations that joined the ECO operate in all major sectors of the economy: agriculture, industry, banking, construction and maintenance of social housing, services, pharmacy, retail. These cooperatives unite 163 million members, have 267 thousand cooperative enterprises with a number of employees of 5.4 million.

The intensification of Ukraine's international economic cooperation provides the development of a strategy for the effective functioning of agricultural cooperation, which is the basis for ensuring the integrated development of rural territories and various forms of employment for rural populations. In addition, agricultural cooperation stimulates the development of infrastructure of agrarian market, plays an exceptional role in strengthening the economic potential, competitiveness and social status of agricultural producers, improving economic conditions and creating incentives for the growth of commodity products. But, so far its development is at a low level, the main reasons for these are the underestimation of cooperative forms of economic activity in the process of economic reforms, general unfavorable conditions for agricultural production, psychological unwillingness of peasants to cooperate and insufficient level of knowledge of rural population about the benefits of cooperation, weak state support of small forms of farming in agro-industrial complex and agricultural cooperatives.

Under such conditions, studying and applying the best practices of formation and functioning of foreign cooperative organizations is extremely important and relevant for Ukraine in the current conditions. In addition, international experience has shown, that cooperation has contributed to the development of many countries in the world. In Europe, for example, cooperatives are an important part of economic life and industry.

A well-developed cooperative in Japan, where farmer cooperatives (8038 agricultural cooperatives, 3898 of which are multifunctional), process and market about $90 \%$ of all agricultural production in the country (including almost 100\% of total grain, 95\% of potatoes, vegetables, fruits and milk, $85-90 \%$ of pork, eggs and poultry) and supply farmers with up to $80 \%$ of the production they need. Japan's complex primary cooperatives at the level of trade unions are combined into federations, different for their functions: mutual aid federations, economic and credit federations, as well as agricultural cooperative boards. The prefectural federations are in turn members of the all-Japan federations. In other words, a centralized cooperative system is set up in the country, the task of which is to 
protect the interests of agricultural producers from monopoly capital. It is quite autonomous with respect to the state. In Japan, as well as in Sweden, Norway and Finland, government representatives, together with agricultural cooperatives, monitor the negotiations of producers and address issues such as the level of prices for agricultural products, budget allocations to agriculture, bank interest rates on credit (in Japan they are in 2-3 times lower than commercial ones), export subsidies, and more.

\section{Findings}

Thus, it is important today to try on foreign experience for agricultural cooperation in Ukraine. That is why the Ministry of Finance of Ukraine considered the letter of the State Fiscal Service of Ukraine No. 1835/4/9999-15-02-02-13 dated July 10, 2019 on the issue of the lawfulness of presence of serving cooperatives, including agricultural serving cooperatives, in the Register of Nonprofit Institutions and Organizations.

Law of Ukraine No. 1087-IV dated July 10, 2003 "On Cooperation" (further - Law No. 1087) defines legal, organizational, economic and social bases of functioning of cooperation in Ukraine.

According to the tasks and the nature of the activity, cooperatives are divided into production, serving and consumer, which according to the directions of their activity may be agricultural, housing, gardening, garage, trade, transport, educational, tourist, medical, etc. (art. 6 of the Law No. 1087).

Article 2 of the Law No. 1087 defines, in particular, the term "service cooperative", which identifies a cooperative, formed by combining individuals and/ or legal entities to provide services mainly to members of the cooperative, as well as to other persons for conducting their business activities. Besides, it is arranged, that service cooperatives provide services to other persons in volumes, not exceeding 20 percent of the cooperative's total turnover.

At the same time, this law determines that cooperatives have the right to carry out any economic activity, provided for in the charter and not prohibited by law (Article 23 of the Law No. 1087).

However, the Law of Ukraine No. 469/97-BP dated July 17, 1997 "On agricultural cooperation" (further the Law No. 469) defined the legal, organizational, economic and financial features of the formation and activity of agricultural cooperatives.

Therefore, the Law No. 469 specifies the term "agricultural cooperative" and defines the division of agricultural cooperatives into production and service ones.

An agricultural service cooperative is an agricultural cooperative, formed by combining natural and/or legal persons, which are producers of agricultural products, to organize services, aimed at reducing costs and/or increasing the income of the members of the cooperative during their agricultural activities and protection of their economic interests (Articles 1, 3 of the Law No. 469).

Article 2, paragraph 2 of the Law No. 469 also sets out that the general principles, concepts and norms of formation, ensuring of functioning, management and liquidation of an agricultural cooperative and cooperative associations, control over their activities, rights and duties of their members, formation of property, funds, prices and tariffs for products and services, as well as labor relations in such cooperatives and associations are regulated by the Law of Ukraine No. 1087.

Besides, Article 4 of the Law No. 469 defines, that the charter of an agricultural cooperative is developed in accordance with the requirements of Article 8 of the Law No. 1087, according to which the statute of any cooperative is a legal document, governing its activity and must contain information, in particular, about the order in which its income is distributed, and coverage of losses.

It is also provided, that the statute may contain other positions, related to the cooperative's activities, which are not contrary to the law.

It should be noted that paragraph 1 of Article 9 of the Law No. 469 regulates the peculiarities of economic activity of agricultural service cooperatives, namely: such cooperatives provide services to their membersproducers of agricultural products, without any purpose of profit, and such cooperatives are non-profit organizations. The profitability of agricultural service cooperatives is determined on the basis of the following features:

- the cooperative provides services only to its members; - the members of the cooperative are responsible for the obligations, undertaken before the cooperative regarding their participation in the economic activities of the cooperative;

- the services are provided in order to reduce costs and/ or increase the income of the cooperative members.

In addition, paragraph 5 of Article 9 of the Law No. 469 determines, that after fulfilling the obligations of an agricultural servicing cooperative and recovering the losses in previous periods, the balance of the cooperative's financial result is distributed by general meeting in the form of contributions to the cooperative's funds, cooperative payments to its members, payments in units to the members of the cooperative, including associated.

The term "cooperative payments in an agricultural servicing cooperative" is defined as the return to the members of a cooperative of a part of the pre-paid value of services, rendered by a cooperative in relation to their actual value, distributed according to the results of the financial year between its members (paragraph 1 of Article 1 of the Law No. 469).

At the same time, the term "cooperative payments" is given in Article 26 of the Law No. 1087, which defines the portion of income, distributed on the results of the 
financial year between the members of a cooperative in proportion to their participation in the cooperative's economic activities in accordance with the decision of the higher management body of the cooperative. It is also stated, that the rule of the Law No. 1087 does not apply to agricultural service cooperatives.

In addition, Article 26 of the Law No. 1087 defines the term "payments in shares", which defines the payment of part of the cooperative's income to the units of a cooperative member.

At the same time, Article 25 of the Law No. 1087 defines, that the income of a cooperative is formed from the income from economic activities after covering the material and related costs and expenses for the wages of employees and is divided into, in particular, cooperative payments and payments in shares.

In accordance to subparagraph 133, paragraph 133.4.1, of Article 133 of the Tax Code of Ukraine (further - Code), non-profit enterprises, institutions and organizations (further - non-profit organizations), meeting the requirements, specified in this subparagraph of the Code, among which there is the prohibition of the distribution of the income (profits) or a part of them among the founders (participants) and the determination in the constituent documents of the nonprofit organization the procedure for transferring assets in the case of termination of the non-profit organization as a legal entity.

These requirements were introduced in connection with the change of the concept of taxation of the nonprofit organizations with the entry into force of the Law of Ukraine of N 652-VIII dated July 17, 2015 "On Amendments to the Tax Code of Ukraine on Taxation of Non-Profit Organizations", which consists in exemption from taxation income, that they may derive from their business activities, using the revenue generated entirely to finance the maintaining of such a non-profit organization, as well as for the realization of the purpose (goals, objectives), defined by its constituent documents.

The conducted research has proved that the agricultural cooperation of the European Union is an economically conditioned ideology of survival of the farmer in the harsh economic conditions, the possibility of ensuring equality in business for farmers, regardless of the size, shape, types or directions of management. The Ukrainian agrarian sector, as well as the European one, is characterized by multifaceted and small-scale production. Therefore, the spread of cooperation in the agrarian sector of the Ukrainian economy should be based on the European principles of democracy, transparency and solidarity, based on comprehensive state support.

Thus, summarizing the experience of the developed countries of the world, it should be noted that the main advantages of combining agricultural producers in cooperatives are (Clutton-Brock, 2002):

1. The individual producer is not able to influence the price level of both the purchase and the sale of manufactured goods to processing enterprises. The Grower Group (Union or Cooperative) is seen as the only powerful organization capable of purchasing large volumes of goods and services and selling large volumes of production.

2. A significant advantage of cooperative associations is the ability to exchange experience between farmers on the effectiveness of farming, as well as the desire to work as a part of association, groups rather than on their own.

3. Due to the joining of farmers' efforts in a single organization, as well as the existence of purchasing raw materials and selling products, the level of profitability of the production increases, and the generated profit is distributed evenly between each participant of the cooperative. At the same time, the cooperative union introduces a unified accounting, as well as a unified system for calculating the cost of production, which reduces its cost by reducing the cost of fixed charge in the enterprise as a whole.

4. Uniting into cooperatives, farmers have the opportunity to increase production by obtaining a loan for their own development, as well as by using the means of production, leased from other members of the cooperative.

6. Officially registered cooperative associations have the opportunity to obtain a preferential loan for investments in agricultural production, processing of production and provision of production services.

7. The cooperative may receive tax exemption or reduction of the tax rate for the construction of new ones, as well as the reconstruction of existing structures, modernization of the material and technical base used within the activity, which is defined by the charter of the enterprise for a period of up to 5 years from the date of entering the cooperative in the state register of groups of agricultural producers.

8. Formally registered cooperatives, both producer groups and farmers association members may receive both logistical and organizational information support from the state. This support includes professional training, farm modernization, certification of products according to the requirements of food quality system, information and promotion activities for farmers, economic, legal support and advisory services for farmers, diversification of economic activities in the field of development of green tourism, etc.

Therefore, taking into account the above mentioned, the possibility of distributing the income (profits) or a part of them between the members of the service cooperatives through the making of cooperative payments and payments in shares is performed by the provisions of the Law No. 1087 (Articles 25, 26).

Similarly, agricultural service cooperatives, in accordance with the provisions of Article 26 of the Law No. 1087, paragraphs 1, 5 of Article 9 of the Law No. 469, may make payments to units as a distribution of a part of the cooperative's income, that may be obtained by an agricultural service cooperative from the provision of services. 
With regard to the order of liquidation of serving cooperatives and agricultural serving cooperatives, it should be noted, that the order of liquidation, defined by Article 29 of the Law No. 1087 does not agree with the provisions of subparagraph 133.4.1 of paragraph 133.4 of Article 133 of the Code in the case of transfer of assets in case of termination of a cooperative as a legal entity, as the paragraph 8 of Article 29 of the Law No. 1087 provides, that the property of the cooperative, which is left after satisfying the requirements of the cooperative's creditors, payments to the members of the cooperative, and payments to the shares, cooperative payments, wages, payments to the cooperative association of which it is distributed between the members in the manner, specified by charter. In addition, the property of the undivided fund is not subject to division between its members and is transferred by the decision of the liquidation commission to the other cooperative organization (cooperative organizations) or credited to the budget income.

However, the existence of these legislative grounds to distribute income to cooperatives, including in the event of their elimination, cannot be a mandatory purpose establishment and operation of service cooperatives and agricultural service cooperatives.

Therefore, the above does not exclude the possibility of bringing service cooperatives and agricultural service cooperatives to bring the provisions of the constituent documents in accordance with the requirements of the Code, which would prohibit the distribution of income (profits) or parts thereof, including the elimination of such cooperatives for inclusion in the register of nonprofit institutions and organizations.

Thus, taking into account the above, service cooperatives and agricultural service cooperatives may be in the Register of non-profit institutions and organizations, provided that their constituent documents comply with the requirements of subparagraph 133.4.1 of clause 133.4 of Article 133 of the Code and compliance in the course of business activities the requirements of subparagraph 133.4.2, the same paragraph of the Code, according to which the income (profits) of a non-profit organization is used solely to finance the expenses for the maintenance of such non-profit organization, realization of the purpose (goals, objectives) and directions of activity, defined by its constituent documents.

At the same time, it should be noted, that subparagraph 133.4.4 of paragraph 134.4 of Article 134 of the Code provides for the powers of supervisory authorities to carry out audits of a non-profit organization in order to identify the facts of the use of income (profits) for purposes other than those specified in subparagraph 133.4 .2 of paragraph 134.4134 of the Code by a non-profit organization, and the exclusion of such an organization from the Register of NonProfit Institutions and Organizations and accrual of tax liability on corporate income tax, penalties and fine in accordance with the norms of the Code.

\section{Conclusions}

Therefore, some foreign experience of developed countries and countries with transition economies on the formation and activity of organizational and economic mechanisms in the creation and operation of cooperative structures, (in particular the statutory provisions related to the determination of unit participation of members of cooperatives, the formation of funds, distribution of economic activities, etc.) can serve as a well-proven source of useful information. Foreign experience of consumer cooperation development can be successfully used in determining the directions, forms and types of implementation of cooperative processes in Ukraine.

Comparison of the world practice of creation and functioning of cooperative structures with real possibilities of cooperative activity in Ukraine shows that in the country this process is in the early stage.

Such a state of development of the Ukrainian cooperation is caused mainly by excessive liberalization of economic and social relations. During the years of transformations, old social conquests have been preserved in Ukraine, but the awareness and legislative registration of new social realities that would reflect the democratic nature of society have not taken place.

All the trends and processes that characterize the international cooperative movement today have been shaped by the experience of cooperative development in the countries of the world in the process of globalization. Ukrainian cooperatives should use the experience of these countries and follow the trends in the sphere of international cooperation.

The solution to this issue is greatly facilitated by the experience of cooperative implementation activities of foreign countries and possibilities of its use for creation and functioning of cooperative formations of Ukraine.

\section{References:}

Aleskerova, Yu. V. (2009). Kredituvannya regional'nogo APK [Lending to regional agribusiness]. Zbirnyk naukovih prac, vol. 17, no. 2, pp. 645-648. Kamianets-Podilskyi.

Aleskerova, Yu., Mulyk, T., \& Fedoryshyna, L. (2018). Improving credit protection analysis methods Reports of main agricultural enterprises. Baltic Journal of Economic Studies, vol. 4, no. 2, pp. 1-7. doi: 10.30525/22560742/2018-4-2-1-7

Aleskerova, Yu., Fedoryshyna, L., \& Koval, N. (2018). Features of loan security for the reproduction of fixed assets for agricultural purposes. Baltic Journal of Economic Studies, vol. 4, no. 4, pp. 1-5. doi: 10.30525/2256-0742/2018-4-4-1-5 
Aleskerova, Yu., \& Todosiychuk, V. (2016). Fiscal multipliers in Ukraine. Economy and management organization, vol. 4(24), pp. 36-43.

Rogach, S., Vdovenko, L., \& Polishchuk, O. (2019). Agriculture of Ukraine under the joint policy of the European Union. Baltic Journal of Economic Studies, vol. 5, no. 3, pp. 178-183. doi: 10.30525/2256-0742/2019-5-3-178-183

Plakhtii, T., Fedoryshyna, L., \& Tomchuk, O. (2019). Socio-economic component of preferential taxation of individuals' incomes. Baltic Journal of Economic Studies, vol. 5, no. 2, pp. 171-175. doi: 10.30525/2256-0742/20195-2-171-175

Polova, O., \& Ruda, O. (2019). Modern Technologies in Economy and Management. Collective Scientific Monograph: The Academy of Administration in Opole.

Todosiichuk, V. L. (2018). Kontseptualni zasady upravlinnia finansovymy resursamy derzhavnoho pidpryiemstva [Conceptual principles of financial resources management of a state-owned enterprise]. Infrastruktura rynku, vol. 26, pp. 56-64.

Kohn, Alfie (1992). No Contest: The Case Against Competition. Houghton Mifflin Harcourt. ISBN 978-0-39563125-6

Fehr, Ernst. "Altruistic punishment in humans" (PDF). Macmillan Magazines Ltd. Archived from the original (PDF) on 29 September 2011. Retrieved 20 July 2011.

Hamilton, W. D. (1964). The Genetical Evolution of Social Behaviour. Journal of Theoretical Biology, vol. 7, pp. 1-16. Frans de Waal (2016). Are We Smart Enough To Know How Smart Animals Are? ISBN 978-1-78378-305-2

Clutton-Brock, T. (2002). Breeding together: Kin selection and mutualism in cooperative vertebrates. Science, vol. 296(5565), pp. 69-72. doi:10.1126/science.296.5565.69

Lindenfors, Patrik (2017). For Whose Benefit? The Biological and Cultural Evolution of Human Cooperation. Springer. ISBN 978-3-319-50873-3

Sakovska, O., \& Shpykuliak, O. (2019). State regulation of the functioning and development of agricultural cooperatives in the grain market. Proceedings of the $33^{\text {rd }}$ International Business Information Management Association Conference, IBIMA 2019: Education Excellence and Innovation Management through Vision 2020. $33^{\text {rd }}$ IBIMA Conference: 10-11 April 2019 Granada, Spain. Editor Khalid S. Soliman.

Yablochnikov, S., Kuptsov, M., Omelchenko, O., Gupta, S. K., Reznik, N., Hatsko, A., \& Sakovska, O. (2019). Modelling of informational counteraction between objects in economy. International Journal of Engineering and Advanced Technology, vol. 8, issue 6, pp. 3797-3802.

Yevdokimova, M., Zamlynskyi, V., Kuznietsov, E., Sakovska, O., \& Hatsko, A. (2018). Evolution of social responsibility applied to the concept of sustainable development: mainstream of the $20^{\text {th }}$ century. Journal of security and sustainability issues, vol. 8, no. 1, pp. 69-78.

Clutton-Brock, T. (2002). Breeding together: Kin selection and mutualism in cooperative vertebrates. Science, vol. 296(5565), pp. 69-72. doi: 10.1126/science.296.5565.69 